\title{
New achromatic telescope
}

\section{Cauchoix}

To cite this article: M. Cauchoix (1827) New achromatic telescope, Philosophical Magazine Series 2, 1:6, 470-470, DOI: 10.1080/14786442708674370

To link to this article: http://dx.doi.org/10.1080/14786442708674370

曲 Published online: 10 Jul 2009.

Submit your article to this journal

Џ Article views: 2

Q View related articles $₫$ 
spertz also lays claim to the discovery of this compound; the ob. tained it as above described, and also by passing chlorine ove boruret of iron.-Ann. de Chim. xxx. 378-442.

\section{NEUTRALIZING THE MAGNETISM OF WATCH-WORKS.}

Mr. Abraham, of Sheffeld, has contrived an extremely easy and effectual mode of divesting watch-works of their magnetism. The process consists in dipping the part to be divested of magnetism, as a balance-wheel, into fine steel filings, and then presenting a fine magnet to the part covered with them, at a distance of a quarter to one inch, according to the power to be neutralized. . It will be directly observed whether the polarity of the magnet be of the same kind as that in the apparatus; if so, the filings will gradually fall from the part as the power becomes neutralized. When all the flings have fallen from the part submitted to experiment, dip it again into the filings, to prove whether it has acquired opposite polarity by remaining too long exposed to the magnet; if that be the case, present the contrary end of the magnet at a distance proportional to the power to be diffused. By this process, exposure to heat is rendered unnecessary. - Trans. Society of Arts, 44-59.

\section{NEW ACHROMATIC TELESCOPE: BY M. CAUCHOIX.}

M. Cauchoix, the optician, of Paris, has nearly completed an achromatic telescope, measuring about nineteen and a half feet in length, with an object-glass by the late M. Guinand, of $12 \frac{3}{4}$ inches diameter. Some remarkable observations on Saturn's ring have atready been made with this instrument, by MM. Arago and $\mathrm{Ma}-$ thieu, the results of which will shortly be published when fully verified.

\section{CHLOUIDE OF ARSENIC.}

Put one part of arsenious acid and 10 parts of concentrated sulphuric acid into a tubulated retort, and raise the temperature to nearly $212^{\circ}$ Fahr.; then throw fragments of fused common salt into the retort by the tubulure. By continuing the heat and successively adding common salt, protochloride of arsenic is obtained; it falls drop by rop from the beak of the retort, and may be collected in cooled vessels : little, if any, muriatic acid is disengaged, but towards the end of the operation a portion of hydrated chloride of arsenic is frequently produced; which collects in the vessels above the pure chloride. The two bodies do not mix; the hydrate is liquid, transparent and colourless, and more viscid than the dry chloride. The hydrate may be decomposed, and pure chloride ob. tained, by distilling the mixture from a sufficient quantity of sulphuric acid.-Dumas. Ann. de Chim.et Phys. xxxini: 360 .

NOTE RESPECTING MR. BABBAGE'S LOGARITHMS.

The logarithm of the number 24626 , whose four last figures are 